\title{
Target Ecosystem Assessment Model: a process to develop target revegetation prescriptions in the mine closure landscape
}

B Logan Paragon Soil and Environmental Consulting Inc., Canada

V Futoransky Paragon Soil and Environmental Consulting Inc., Canada

S Dietrich Paragon Soil and Environmental Consulting Inc., Canada

BH Flemming Paragon Soil and Environmental Consulting Inc., Canada

V Wilson Paragon Soil and Environmental Consulting Inc., Canada

L Waterman Paragon Soil and Environmental Consulting Inc., Canada

\begin{abstract}
The Target Ecosystem Assessment Model (TEAM) was developed to provide mine reclamation practitioners with an iterative process to refine final closure reclamation plans. Using the ArcGIS ${ }^{\text {TM }}$ platform, it incorporates inputs from multiple sources including soil cover design; topography; hydrology and wetlands; soil nutrient regime and stakeholder inputs to develop revegetation prescriptions for target ecosystems.

The model output is used to guide vegetation prescription suitability with an appropriate predicted relative moisture (driest to wettest) regime. To develop the TEAM, various input layers are overlaid sequentially to create unique relative estimated moisture regime areas. Slope position and soil texture are influential factors of moisture regime in areas not directly influenced by the water table. In transitional areas and wetland areas, topographic position and proximity to water and/or water table are more influential to moisture regime predictions. With this information, a range of suitable target revegetation prescriptions can be generated from estimated relative moisture regime derived from the model and nutrient regime derived from the soil cover characteristics (i.e. the soil prescription).

The output of the model provides planners with a range of moisture classes tied to specific ecosystems, and the soil and vegetation prescriptions that support them. The TEAM reduces the potential subjectivity of planning by matching ecosystem target options to each unique combination of site conditions, and in doing so, testing for mismatches in site conditions and desired end land uses. The TEAM provides flexibility in creating the target ecosystem layouts, by including stakeholder input for desired end land use and consideration of the complexity and arrangement of ecosystems in the pre-disturbance landscape. This information is used to further delineate areas for specific revegetation prescriptions (targeted vegetation community assemblages). Planners who use the TEAM can be confident in defensible target ecosystem layouts, which are developed using a standard, tested procedure.
\end{abstract}

Keywords: target ecosystems, mine closure planning, reclamation plan, model, soil prescriptions, moisture regime, nutrient regime, revegetation prescriptions

\section{Introduction}

Mine closure planning, and specifically developing a detailed life-of-mine closure plan (LMCP) is a regulatory requirement for oil sands mines in Alberta, Canada under the Environmental Protection and Enhancement Act (EPEA) (Government of Alberta 1993). In general, LMCPs provide proposed conservation and reclamation strategies, and conceptual and integrated reclamation planning for the life of the project to achieve sustainable environmental outcomes after mine closure (Alberta Energy Regulator (AER) 2018). Under the 
EPEA and industry operating approvals, disturbed lands in northern Alberta must be reclaimed to a 'selfsustaining, locally common boreal forest ecosystem, integrated with the surrounding area...'. The LMCP must address the full life of the project, and align with regional plans, tailings management plans, the operating approval, and commitments made in the original application; results from current research and performance measurements must also be incorporated into the planning (AER 2018).

Developing a detailed LMCP that meets the regulatory requirements is a very complex process that requires time and a high level of effort from a multi-disciplinary team. An LMCP must:

- Return an acceptable distribution of upland and wetland ecosystem types on the closure landscape.

- Integrate landforms, topography, vegetation, water bodies and watercourses with undisturbed areas and mine areas.

- Consider tailings capping requirements, surface and groundwater hydrology, the reclamation material balance, wetlands, vegetation communities, forest resources, end land uses (traditional, recreational, commercial), pit lakes, wildlife habitat, and watercourse and riparian design.

Creating a closure landscape, complete with spatially explicit areas outlining specific soil reclamation prescriptions and targeted vegetation communities can be subjective, inconsistent and not replicable, depending on the focus of the design team and the shifting priorities of stakeholder end land use requests.

After working on LMCPs for several oil sands mines in northern Alberta, Canada, it was evident that stronger integration of available multi-disciplinary data, and incorporating the information in a Geographic Information System (GIS) environment, were key areas for improvement to develop logical, robust, consistent, defensible and specific plans for mine closure. In response, the Target Ecosystem Assessment Model (TEAM) was developed as a process-based conceptual model that uses available spatial inputs (layers) including data for geomorphic landform design, hydrology, hydrogeology, pit lake design, reclamation, and wildlife habitat (multi-disciplinary data), that combines these elements using GIS overlay analysis. By using the best available dataset for each variable, confidence in the output is increased; however, even using basic information can yield a logical relative estimated moisture regime (REMR) output.

The key output of the TEAM is a REMR for all areas on the closure landscape along a relative gradient from driest to wettest. The REMR areas are used in combination with other stakeholder inputs (e.g. desired end land use, vegetation communities and wildlife habitat types, operational reclamation area size/preferred patch size, retention of facilities on the landscape etc.), and with consideration of the complexity and arrangement of ecosystems in the pre-disturbance landscape to delineate areas for specific revegetation prescriptions (targeted vegetation community assemblages). The closure ecosystem layout (revegetation prescriptions) is one of the main products of the LMCP, and provides evidence to the regulatory body that the LMCP yields a 'self-sustaining, locally common boreal forest ecosystem, integrated with the surrounding area'.

The TEAM includes integration of existing research and reclamation monitoring data, along with spatial data from a multi-disciplinary team in a GIS environment, that reduces the subjectivity, inconsistency and time required to develop target ecosystems in the mine closure landscape. This paper provides the high-level methods used in the TEAM process, and includes examples of the model inputs, the resulting REMR (model output), potential additional considerations (stakeholder input), and an interpretation of a closure ecosystem layout. Using geographically specific data, this process can be used to model REMR in any location to support reclamation planning purposes. 


\section{Methodology}

The types of model inputs and the GIS platform are universal data sources for closure planning in other jurisdictions and geographic locations. To identify target ecosystems and revegetation prescriptions for closure planning, the TEAM is used to generate REMR areas (the model output) using a scale of one (very dry) to nine (very wet) across the mine closure landscape. Available spatial inputs (layers) are created, analysed, and processed in Python, which allows for spatial analysis and mapping within the ArcGIS ${ }^{\mathrm{TM}}$ platform. Three key categories of variables are used:

1. Available water holding capacity (AWHC).

2. Topography.

3. Hydrology, wetlands and flow path analysis.

REMR areas are further refined using predicted soil nutrient regimes (SNR) associated with soil reclamation prescriptions, along with additional stakeholder input to guide further delineation of specific revegetation prescriptions. An overview of the process is illustrated in Figure 1.

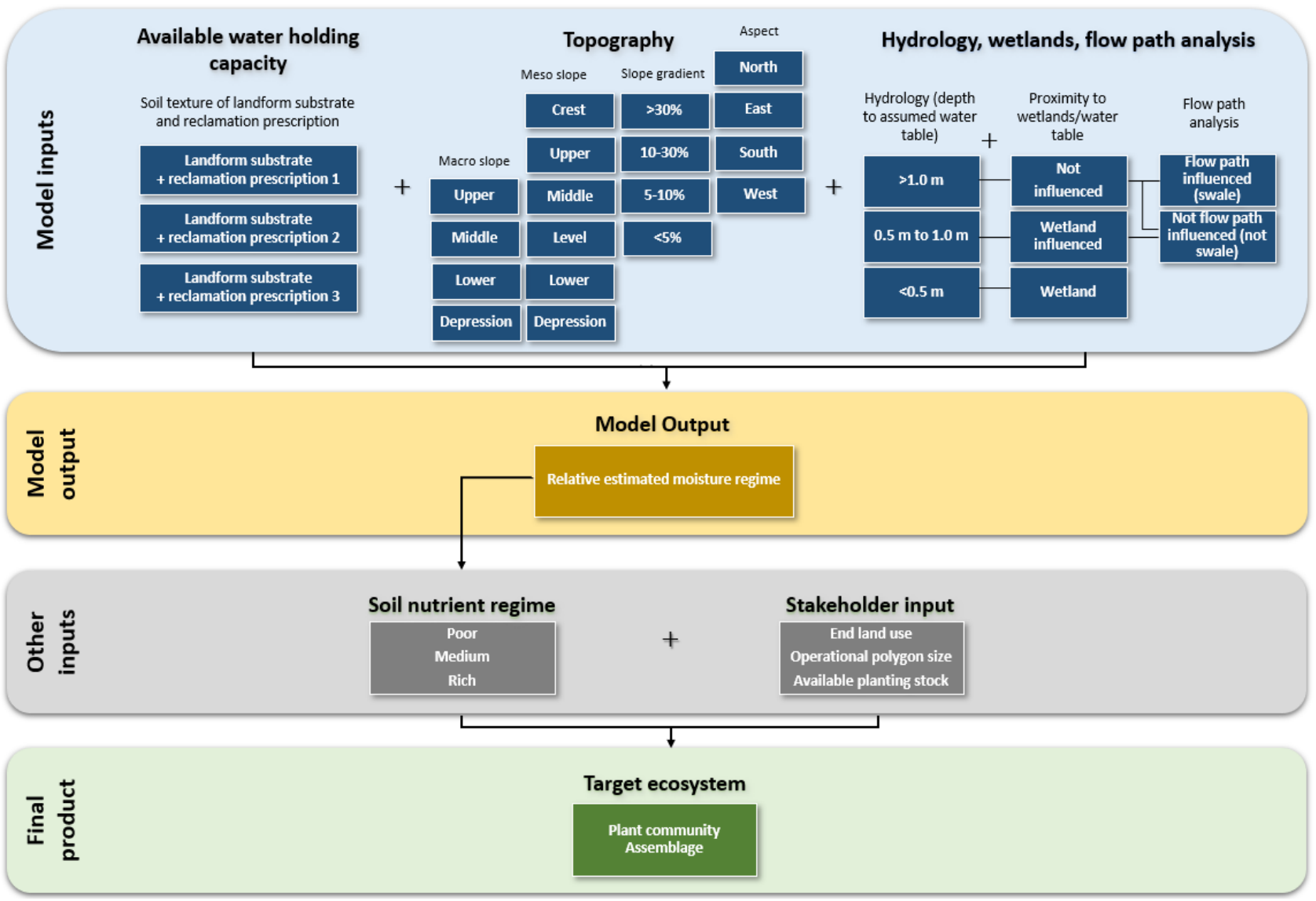

Figure 1 High-level overview of the Target Ecosystem Assessment Model process

\subsection{Model inputs}

\subsubsection{Available water holding capacity}

Soil texture (e.g. particle size distribution) of the materials that make up the landform substrate (e.g. overburden, tailings sand) and the overlying soil prescription have an effect on the ability of the reclamation profile to hold water. In general, coarse-textured materials decrease AWHC while medium to fine-textured materials increase AWHC. The known or assumed characteristics of each landform's substrate are used to create a substrate layer, which is then used to determine the AWHC of that layer. A base texture 
REMR value is determined for each substrate texture class using a simple linear regression between AWHC and moisture regime as described in the Land Capability Classification System for Forest Ecosystems in the Oil Sands, 3rd Edition (LCCS) (Alberta Environment 2006). When soil texture and its corresponding AWHC value is known for a profile $100 \mathrm{~cm}$ thick $(x)$ during the initial soil placement stage, the REMR value $(y)$ can be calculated using Equation 1:

$$
y=0.0334 x-0.3351
$$

Table 1 illustrates base REMR value relationships with AWHC for common soil texture.

Table 1 Relative estimated moisture regime derived from soil texture and available water holding capacity

\begin{tabular}{lcc}
\hline Soil texture* & $\begin{array}{c}\text { Available water holding } \\
\text { capacity (mm)** }\end{array}$ & $\begin{array}{c}\text { Base relative estimated } \\
\text { moisture regime by texture }\end{array}$ \\
\hline Sand & 80 & 2.3 \\
Tailing sand, buried organic & 100 & 3.0 \\
Loamy sand & 110 & 3.3 \\
Sandy loam & 140 & 4.3 \\
Loam, sandy clay, sandy clay loam & 150 & 4.7 \\
Clay, silty clay loam, silty clay & 160 & 5.0 \\
Clay loam & 170 & 5.3 \\
Silt loam, silt, silty sand & 180 & 5.7 \\
\hline
\end{tabular}

* Assuming $100 \mathrm{~cm}$ of soil depth is used (Alberta Environment 2006). ${ }^{* *}$ From the LCCS Calculator (Alberta Environment 2006)

Various reclamation cover designs (soil prescriptions) are typically applied over the landform substrate during the second stage of soil placement, which could alter the base AWHC and REMR. To determine the base texture REMR for the full soil profile (i.e. the soil prescription overlying the substrate), the AWHC of all likely combinations of soil prescriptions should be assessed using typical or known soil textures to determine a potential low and high level for each substrate type (Table 2). This range offers flexibility in predicted REMR values for each substrate type.

Table 2 Relative estimated moisture regime range applied to substrate and soil prescriptions using soil texture

\begin{tabular}{|c|c|c|c|c|c|}
\hline \multirow[t]{2}{*}{ Substrate examples } & \multirow[t]{2}{*}{$\begin{array}{l}\text { Substrate } \\
\text { texture* }\end{array}$} & \multicolumn{2}{|c|}{$\begin{array}{l}\text { Available water holding } \\
\text { capacity for full soil } \\
\text { prescription }(\mathrm{mm})^{* *}\end{array}$} & \multicolumn{2}{|c|}{$\begin{array}{l}\text { Base relative } \\
\text { estimated moisture } \\
\text { regime by texture }\end{array}$} \\
\hline & & Low & High & Low & High \\
\hline Subsoil - coarse & Sand & 85 & 125 & 2.5 & 3.8 \\
\hline Coarse sand tailings & Loamy sand & 100 & 140 & 3.0 & 4.3 \\
\hline Overburden & Sandy loam & 115 & 155 & 3.5 & 4.8 \\
\hline Subsoil - fine & Sandy clay loam & 120 & 160 & 3.7 & 5.0 \\
\hline
\end{tabular}

* Assuming $100 \mathrm{~cm}$ of soil depth is used (Alberta Environment 2006). ${ }^{* *}$ From the LCCS (Alberta Environment 2006), assuming a $0.5 \mathrm{~m}$ soil prescription profile overlying landform substrate 


\subsubsection{Topography}

The slope position, grade and orientation of a site on the closure landscape also has an effect on the ability of the final reclamation profile to hold water, which is a critical component of determining the REMR of each area. These topographic variables are derived from a provided Digital Elevation Model (DEM) and their relevance to REMR determination are further described in Table 3 and the following subsections.

Table 3 Topography model inputs applicable to relative estimated moisture regime

\begin{tabular}{|c|c|c|}
\hline Variable & Class & Applicability to relative estimated moisture regime \\
\hline \multirow[t]{4}{*}{$\begin{array}{l}\text { Macro slope } \\
\text { position }\end{array}$} & Upper & $\begin{array}{l}\text { Uppermost portion of a landform (e.g. hill/dump), generally with a } \\
\text { convex slope profile (surface water-shedding) }\end{array}$ \\
\hline & Middle & $\begin{array}{l}\text { The area in between the upper slope and lower slope where the general } \\
\text { slope profile is not distinctly concave or convex (surface water } \\
\text { through-flow) }\end{array}$ \\
\hline & Lower & $\begin{array}{l}\text { The area towards the bottom or base of a landform where the general } \\
\text { slope profile is generally concave (surface water receiving) }\end{array}$ \\
\hline & Depression & $\begin{array}{l}\text { The lowest part of a valley system, bounded on both sides by steeper } \\
\text { slopes (typically defined by wetland areas) }\end{array}$ \\
\hline \multirow[t]{6}{*}{$\begin{array}{l}\text { Meso slope } \\
\text { position }\end{array}$} & Crest & $\begin{array}{l}\text { The generally convex uppermost portion of a landform, usually convex in } \\
\text { multiple directions resulting in no distinct aspect (surface } \\
\text { water-shedding) }\end{array}$ \\
\hline & Upper & $\begin{array}{l}\text { The generally convex upper portion of a slope immediately below the } \\
\text { crest, usually having a convex surface profile with a specific aspect } \\
\text { (surface water-shedding) }\end{array}$ \\
\hline & Middle & $\begin{array}{l}\text { The area of a slope that falls between the upper and lower slope } \\
\text { positions, not usually convex or concave but with a sigmoidal or straight } \\
\text { surface profile with a distinct aspect (surface water through-flow) }\end{array}$ \\
\hline & Level & $\begin{array}{l}\text { Flat areas without a distinct slope or aspect (neither surface } \\
\text { water-shedding nor receiving) }\end{array}$ \\
\hline & Lower & $\begin{array}{l}\text { The area towards the base of a slope, generally with a concave surface } \\
\text { profile and a distinct aspect (includes toe slopes) (surface water } \\
\text { receiving) }\end{array}$ \\
\hline & Depression & $\begin{array}{l}\text { Areas that tend to be concave in all directions, generally at the foot of } \\
\text { slopes (surface water receiving) }\end{array}$ \\
\hline \multirow{4}{*}{$\begin{array}{l}\text { Slope } \\
\text { gradient }\end{array}$} & $\geq 30 \%$ slope & Steep (more water-shedding) \\
\hline & $10 \% \leq x<30 \%$ & Moderate/average \\
\hline & $5 \% \leq x<10 \%$ & Gentle (less water-shedding) \\
\hline & $x<5 \%$ & Level \\
\hline \multirow{4}{*}{$\begin{array}{l}\text { Slope } \\
\text { aspect } \\
\text { (when } \\
\text { slopes } \geq 5 \% \text { ) }\end{array}$} & North & Cooler or warmer dependent on hemisphere \\
\hline & East & Average \\
\hline & South & Warmer or cooler dependent on hemisphere \\
\hline & West & Average \\
\hline
\end{tabular}




\subsubsection{Macro and meso slope position}

Slope position is an influential factor on moisture regime. The predominant source of water on ridges or upper slope positions is precipitation, while middle slope positions typically receive precipitation and some seepage or interflow from upper slopes. Seepage and proximity to moving or standing water is more typical of lower slope positions and flat or depressional areas. Since ecological moisture regime is strongly influenced by a site's position on a slope, topographic position derived at both the landform (macro) to local catchment area (meso) are used in this model.

Macro slope position relates to the broad topographic position on each mining landform from the tops of hills (upper slopes) to the base of channels, defined wetland areas, and depressions (e.g. pit lakes). Each landform and nested catchment area provided are reviewed to determine four major classes of topographic position across the closure area (Table 4). While initially based on the DEM (elevation contour lines and surface shape), macro slope position classification can be refined manually within each landform using professional judgement (especially in areas of subtle topography).

Table 4 Base relative estimated moisture regime derived from topographic slope position

\begin{tabular}{lcccc}
\hline $\begin{array}{l}\text { Meso slope } \\
\text { position }\end{array}$ & \multicolumn{4}{c}{ Macro slope position } \\
\hline Crest & Upper & Middle & Lower & Depression \\
Upper & 3.5 & 3.2 & 4.0 & 5.0 \\
Middle & 4.2 & 4.2 & 5.0 & 6.0 \\
Level & 4.7 & 5.0 & 5.7 & 6.7 \\
Lower & 5.0 & 5.7 & 6.2 & 7.2 \\
Depression & 6.0 & 6.7 & 7.5 & 7.5 \\
\hline
\end{tabular}

Meso slope position relates to the relative position of a reclamation area within a local catchment or slope segment, consistent with the scale of topography affecting localised surface water flow. The Topographic Position Index (TPI) is calculated using a set comparison distance of $75 \mathrm{~m}$ to acquire the necessary level of detail required for this parameter; however, this distance can be modified as appropriate depending on the scale of landforms in the closure landscape. Meso slope positions used in the model are listed in Table 4.

After applying a predicted ecological moisture regime (on a scale of 1 [very dry] to 9 [very wet]) to macro and meso slope combination by an interpretation of topographic position on the closure landscape, the average base topographic REMR value is calculated for each unique topographic position combination across the closure landscape (Table 4).

\subsubsection{Slope gradient and aspect}

Slope gradient is derived by running the slope analysis tool in ArCGISTM on the DEM provided. Four classes are created from level (slope has no influence on water-shedding) to steep (slope has a greater influence on water-shedding) (Table 5). Slope class breaks and names are based approximately on those outlined in the Canadian System of Soil Classification (Soil Classification Working Group 1998) and can be adjusted to accommodate classifications for any geographical area.

Slope aspect is derived by running the aspect analysis tool in $\operatorname{ArcGIS}^{\mathrm{TM}}$ on the DEM provided; however, it can be further refined using solar radiation influence instead of simple cardinal directions (Table 5). Aspect is not applied to level areas (i.e. slope gradient $<5 \%$ ). East and west facing slopes are considered similar to level, while north-facing slopes are generally cooler and south facing slopes are generally warmer (as an example in the northern hemisphere). 
While slope gradient and aspect are influential on REMR, they are somewhat less so than topographic position. As such, the base topographic REMR value developed using landscape position is then modified using slope gradient and aspect available water holding capacity adjustments derived from the Land Capability Classification System for Forest Ecosystems in the Oil Sands, 3rd Edition (LCCS) calculator (Alberta Environment 2006) and adjusted to the REMR scale (Table 5). These adjustments can be applied using classifications from any geographical area.

Table 5 Relative estimated moisture regime adjustments from slope gradient and aspect

\begin{tabular}{|c|c|c|c|c|}
\hline $\begin{array}{l}\text { Slope gradient } \\
\text { class }\end{array}$ & $\begin{array}{l}\text { Meso slope } \\
\text { position }\end{array}$ & Slope aspect class & $\begin{array}{l}\text { Slope adjustment for } \\
\text { available water holding } \\
\text { capacity }(\mathrm{mm})^{*}\end{array}$ & $\begin{array}{c}\text { Relative estimated } \\
\text { moisture regime } \\
\text { adjustment }\end{array}$ \\
\hline \multirow{8}{*}{$\begin{array}{l}\text { Steep or } \\
\text { moderate }\end{array}$} & Crest & Any aspect & -15 & -0.15 \\
\hline & \multirow[t]{3}{*}{ Upper } & South & -30 & -0.65 \\
\hline & & East, west or level & -15 & -0.15 \\
\hline & & North & 0 & 0 \\
\hline & \multirow{3}{*}{$\begin{array}{l}\text { Middle and } \\
\text { lower }\end{array}$} & South & -30 & -0.65 \\
\hline & & East, west or level & 0 & 0 \\
\hline & & North & +15 & +0.15 \\
\hline & $\begin{array}{l}\text { Level and } \\
\text { depression }\end{array}$ & Any aspect & 0 & 0 \\
\hline Gentle or level & $\begin{array}{l}\text { Any slope } \\
\text { position }\end{array}$ & Any aspect & 0 & 0 \\
\hline
\end{tabular}

* From the LCCS (Alberta Environment 2006)

\subsubsection{Hydrology, wetlands and flow path analysis}

Several hydrology-related characteristics can be considered depending on the mine plan. Hydrogeology model output can depict the depth to water table across the closure landscape and indicate the locations of wetlands, transitional areas and uplands. Wetland locations can also be provided in site-wide drainage plans and professional judgement is used to determine extent of transitional areas surrounding wetlands. In all cases, a flow path analysis using the flow accumulation tool in ArcGIS on the DEM is completed across all landforms to determine the locations where water is most likely to accumulate and flow (e.g. swales). Where depth to water table information is provided as part of the hydrogeological modelling, the locations of wetlands, transitional areas and uplands are assigned as provided in Table 6.

Table 6 Hydrologic feature definition based on predicted water table position

\begin{tabular}{ll}
\hline Hydrologic feature & Predicted water table position \\
\hline $\begin{array}{l}\text { Open water features (e.g. pit lakes, } \\
\text { marshes, littoral areas etc.) }\end{array}$ & At or above the ground surface $(<0 \mathrm{~m})$ \\
$\begin{array}{l}\text { Other wetlands (e.g. bogs and fens) } \\
\text { Transitional areas (e.g. swamps) }\end{array}$ & Within $0.5 \mathrm{~m}$ of the ground surface \\
Upland areas (non-wetlands) & Between $0.5 \mathrm{~m}$ and $1.0 \mathrm{~m}$ below the ground surface \\
\hline
\end{tabular}


The REMR values for open water features (e.g. pit lakes, marshes, stream channels) and vegetated wetlands with reduced open water components (e.g. fens, bogs) are hard coded as 9 (very wet) and 8.5 (wet to very wet), respectively (Table 7).

Swales are identified and manually delineated within upland and transition areas using the flow accumulation tool in $\mathrm{ArCGIS}^{\mathrm{TM}}$. In general, this tool calculates flow as the accumulated weight of all cells flowing into each downslope cell of the output raster. Cells with a relatively high flow accumulation are considered to be areas of concentrated flow and are used to identify potential swales. REMR values in transitional areas are hard coded (values set between 5.5 and 8) based on meso slope position and whether or not they are located within a swale (Table 7).

Table $7 \quad$ Hard codes applied to areas by reclamation land cover

\begin{tabular}{|c|c|c|c|c|c|c|}
\hline \multirow[t]{2}{*}{$\begin{array}{l}\text { Land cover type (depth } \\
\text { to water table) }\end{array}$} & \multirow[t]{2}{*}{$\begin{array}{l}\text { Macro slope } \\
\text { position }\end{array}$} & \multirow[t]{2}{*}{$\begin{array}{l}\text { Meso slope } \\
\text { position }\end{array}$} & \multicolumn{2}{|c|}{$\begin{array}{l}\text { Relative estimated } \\
\text { moisture regime for } \\
\text { areas not in swale }\end{array}$} & \multicolumn{2}{|c|}{$\begin{array}{l}\text { Relative estimated } \\
\text { moisture regime for } \\
\text { areas in swale }\end{array}$} \\
\hline & & & Low & High & Low & High \\
\hline $\begin{array}{l}\text { Open water wetlands } \\
\text { (water table at or above } \\
\text { surface) }\end{array}$ & $n / a$ & $n / a$ & 9.0 & 9.0 & 9.0 & 9.0 \\
\hline $\begin{array}{l}\text { Other wetlands (water } \\
\text { table between surface } \\
\text { and } 0.5 \mathrm{~m} \text { ) }\end{array}$ & $\mathrm{n} / \mathrm{a}$ & $n / a$ & 8.5 & 8.5 & 8.5 & 8.5 \\
\hline \multirow{6}{*}{$\begin{array}{l}\text { Transitional areas (water } \\
\text { table between } \\
0.5 \text { and } 1.0 \mathrm{~m} \text { ) }\end{array}$} & $\mathrm{n} / \mathrm{a}$ & Depression & 7.5 & 7.5 & 8.0 & 8.0 \\
\hline & $\mathrm{n} / \mathrm{a}$ & Lower & 7.0 & 7.0 & 7.5 & 7.5 \\
\hline & $\mathrm{n} / \mathrm{a}$ & Level & 6.7 & 6.7 & 7.5 & 7.5 \\
\hline & $\mathrm{n} / \mathrm{a}$ & Middle & 6.5 & 6.5 & 7.5 & 7.5 \\
\hline & $\mathrm{n} / \mathrm{a}$ & Upper & 6.0 & 6.0 & 7.0 & 7.0 \\
\hline & $\mathrm{n} / \mathrm{a}$ & Crest & 5.5 & 5.5 & 6.5 & 6.5 \\
\hline \multirow{4}{*}{$\begin{array}{l}\text { Upland areas (water } \\
\text { table below } 1.0 \mathrm{~m} \text { ) }\end{array}$} & Depression & $n / a$ & \multirow{4}{*}{\multicolumn{2}{|c|}{$\begin{array}{l}\text { Default to } \\
\text { topography-texture } \\
\text { determination } \\
\text { (see Section 2.2.1) }\end{array}$}} & 7.5 & 7.5 \\
\hline & Lower & $\mathrm{n} / \mathrm{a}$ & & & 6.5 & 6.5 \\
\hline & Middle & $\mathrm{n} / \mathrm{a}$ & & & 5.7 & 5.7 \\
\hline & Upper & $n / a$ & & & 5.0 & 5.0 \\
\hline
\end{tabular}

Areas not identified as wetlands or transitional (i.e. upland areas) have REMR values determined by macro slope position and swale presence. If an upland area is within a swale it receives similar higher (wetter) REMR value, similar to if it were in a transitional area (hard coded between 5.0 and 7.5). Upland areas located outside of swales use default REMR values (low and high range) as determined by topography and soil texture in Section 2.2.1.

\subsection{Manipulating model inputs}

\subsubsection{Combining topography and texture}

Decreasing soil particle size (i.e. from coarse- to fine-textured) is also related to increasing available soil moisture; however, texture is typically more influential at upper to middle slope positions. At lower slope positions, soil texture is less of a factor because of other drivers, such as reduced distance to temporary or 
permanent seepage or water table, that become more influential. It is necessary to apply a weight or proportion to each of the estimated REMR values by topography and both lower and upper limits by substrate/texture when combining these elements. The relative weights used in the model are presented in Table 8 for texture and topography; the values used for weighting can be adjusted depending on local climate and site factors.

Table 8 Proportional weight of final relative estimated moisture regime from texture and topography

\begin{tabular}{lcccc}
\hline $\begin{array}{l}\text { Meso slope } \\
\text { position }\end{array}$ & \multicolumn{3}{c}{ Macro slope position } \\
& Upper* & Middle* & Lower* & Depression* \\
\hline Crest & $45: 55$ & $40: 60$ & $30: 70$ & $25: 75$ \\
Upper & $40: 60$ & $35: 65$ & $25: 75$ & $20: 80$ \\
Middle & $35: 65$ & $30: 70$ & $20: 80$ & $15: 85$ \\
Level & $30: 70$ & $25: 75$ & $15: 85$ & $10: 90$ \\
Lower & $25: 75$ & $20: 80$ & $10: 90$ & $5: 95$ \\
Depression & $20: 80$ & $15: 85$ & $5: 95$ & $0: 100$ \\
\hline
\end{tabular}

* Values provided are in percent proportion as a ratio (texture: topography) (e.g. final REMR for an area in a crest [meso] and upper [macro] slope position is weighted $45 \%$ related to texture and $55 \%$ related to topography).

\subsubsection{Assigning final relative estimated moisture regime range}

Once all areas are assigned a final REMR (low and high) value from topography-texture (default) or hard coded as per depth to water table, these variables are averaged for each area. The mean value is used to assign the area to a final REMR class as outlined in Table 9 . The mean range splits provided in Table 9 can be refined for specific climate and site conditions, and are considered to be a sliding scale, making the REMR output customisable to most sites. Using field plot data is another way to test and scale the final REMR class in an adjacent area to match actual ground conditions when known.

Table 9 Final relative estimated moisture regime

\begin{tabular}{cl}
\hline $\begin{array}{l}\text { Relative estimated moisture } \\
\text { regime average range }\end{array}$ & Relative estimated moisture regime class \\
\hline$<3.3$ & (2 to 3) Dry to moderately dry \\
3.3 to 3.7 & (3 to 4) Moderately dry to moderately moist \\
3.8 to 4.2 & (4) Moderately moist \\
4.3 to 4.7 & (4 to 5) Moderately moist to moist \\
4.8 to 5.2 & (5) Moist \\
5.3 to 5.6 & (5 to 6) Moist to very moist \\
5.7 to 6.3 & (6) Very moist \\
6.4 to 6.5 & (6 to 7) Very moist to moderately wet \\
6.7 to 7.4 & (7) Moderately wet \\
7.5 & (7 to 8 ) Moderately wet to wet \\
8.0 & (8) Wet \\
8.5 & (8 to 9) Wet to very wet \\
9.0 & (9) Very wet \\
\hline
\end{tabular}




\subsection{Other inputs}

\subsubsection{Soil nutrient regime}

The REMR (determined above) and expected soil nutrient regime associated with soil prescriptions are used to determine a logical range of plant community types (ecosystems) that are suitable for each upland, transitional and wetland area.

The soil prescriptions (cover designs) used within a closure plan are determined based on the available reclamation material balance, considering pre-disturbance material types and soil handling practices. The soil nutrient regime for each selected soil prescription is estimated based on available soil fertility information (either pre-disturbance or within soil stockpile), including carbon and nitrogen values. At this stage of planning, it is useful to categorise the soil prescriptions into broad soil nutrient regime categories (poor, medium and rich).

\subsubsection{Stakeholder input}

Additional stakeholder input further refines the plant community assemblage selection and ultimately the desired spatial arrangement of revegetation prescriptions across the mine closure landscape. Collaboration with multiple stakeholders to determine the suite of revegetation species to be used across the landscape is an important step. For example, stakeholder input may include, but is not limited to:

- Desired end land use (target vegetation species and planting densities will be different depending on end land use - e.g. specific wildlife habitat type, traditional Indigenous uses, areas allocated for specific commercial forestry tree species, existing facilities retained for community use).

- Desired operational reclamation area size (how small an area is feasible to manage on the closure landscape?).

- Available planting stock (plant species that are commercially available for planting).

- Level of integration with surrounding landscape (edge matching to the adjacent undisturbed landscape, matching closure target ecosystem proportions to pre-disturbance values, using similar reclamation area shapes and orientations to those which existed prior to disturbance).

\subsection{Final product}

Combining the REMR with the soil nutrient regime and other stakeholder input allows the user to define the suite of plant species most suitable and desirable for the reclaimed landscape. The final step in the process is to create the spatial arrangement (the map) of revegetation prescriptions across the landscape. This part of the process is extremely flexible, allowing users to design the final closure ecosystem layout within logical, defensible and robust REMR areas.

Going from REMR to closure revegetation prescriptions for target ecosystems in map form requires the ability to understand the ecology of the area and plant species are available for use, interpret the end land use conditions and corresponding ecosystem characteristics, and use professional judgement based on practical experience and site knowledge. It is often advantageous to place the most challenging-to-reclaim ecosystems on the closure landscape as a first priority, especially if site or soil conditions, planting materials, or other spatial constraints exist. Once these more challenging ecosystems are allocated, it is easier to distribute and map those that have fewer restrictions. 


\section{$3 \quad$ Results}

As noted, the final closure ecosystem layout (or map) can be variable depending on the parameters available to input into the TEAM and the level of additional considerations and decisions from stakeholders. For the purpose of this paper, a representative closure landscape was created to demonstrate various example inputs and outputs (results) of the TEAM process.

\subsection{Model inputs}

Model inputs used in the TEAM are themed and illustrated in Figure 2. A number of different substrate materials are found within the example closure landscape with different corresponding soil textures, ranging from coarse-textured tailings and overburden features to more fine-textured overburden and lower subsoil features (Figure 2(a)). Topographic characteristics, such as macro and meso slope position, slope gradient and slope aspect, are also shown (Figure 2(b) to 2(e), respectively). Finally, a combination of land cover types assigned to either upland, transition or wetland - with and without swales - make up the final model inputs, depending on the estimated depth to water table (Figure 2(f)).
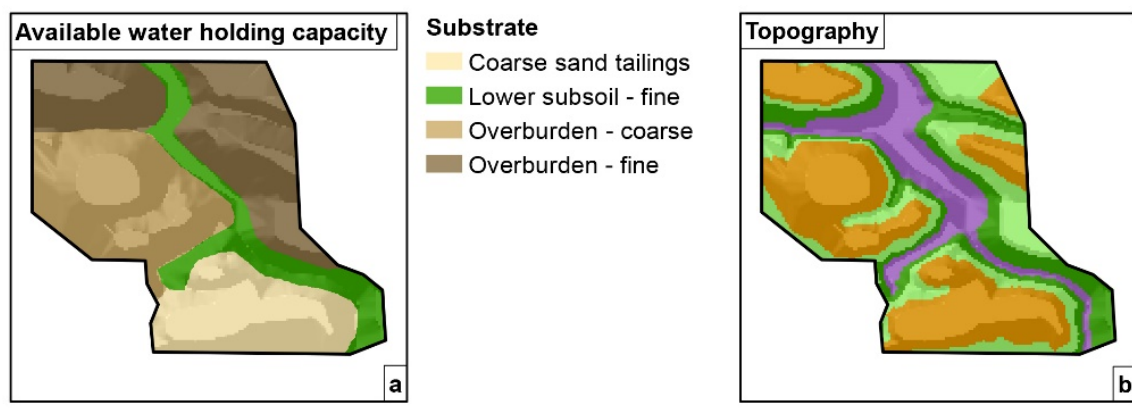

$$
\begin{aligned}
& \text { Macro slope position } \\
& \text { Upper } \\
& \text { Middle } \\
& \text { Lower } \\
& \text { Depression }
\end{aligned}
$$
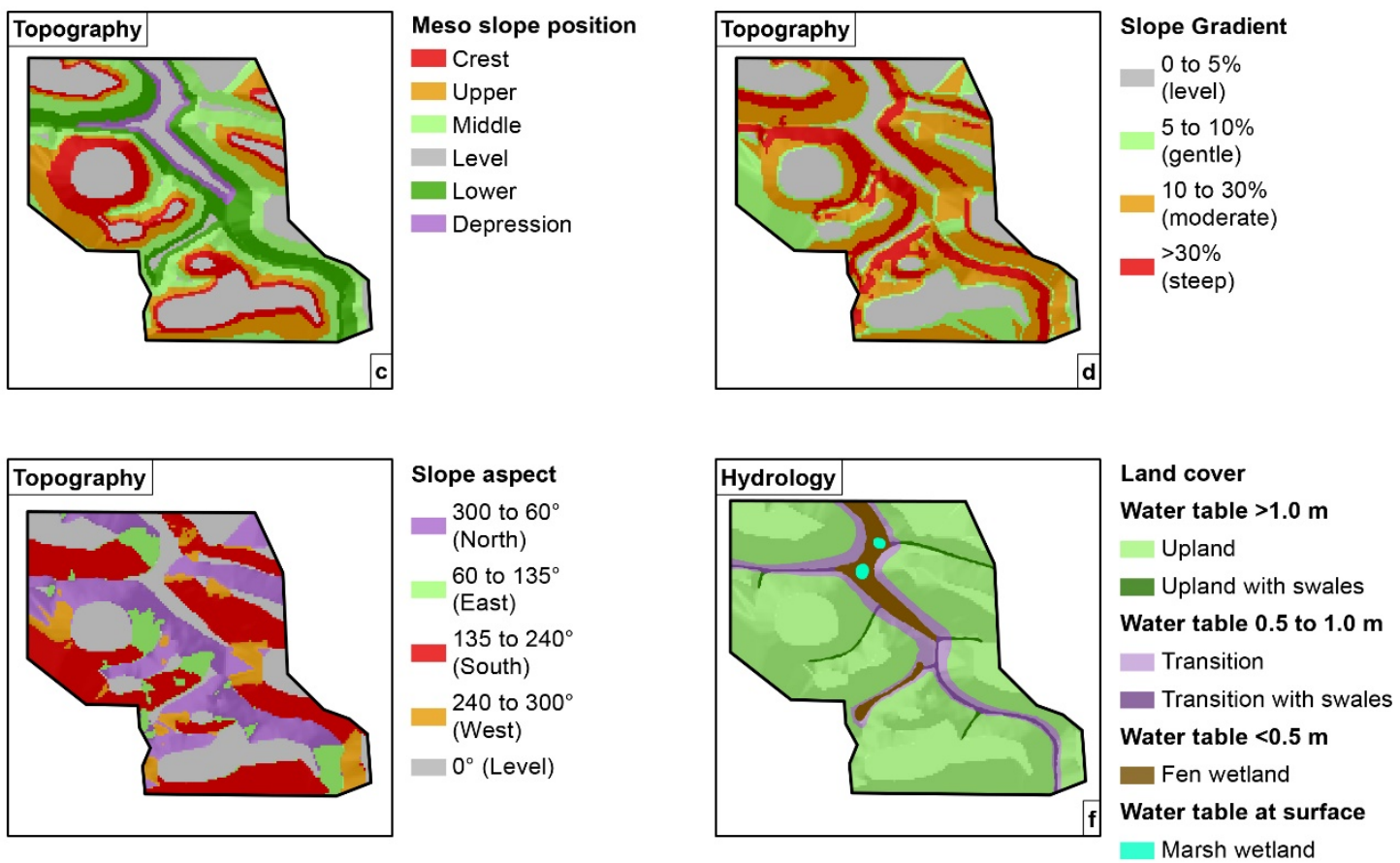

Figure 2 Example model inputs to the Target Ecosystem Assessment Model showing (a) Available water holding capacity; (b) Macro slope position; (c) Meso slope position; (d) Slope gradient; (e) Slope aspect; (f) Hydrology inputs for a hypothetical area 


\subsection{Model and revegetation prescription outputs}

The resulting model output REMR shows a range of estimated soil moisture regime classes from dry to moderately dry (2 to 3 ) through to very wet (9) in the example closure landscape (Figure 3(a) and 3(b)). As expected, the driest areas are associated with crests and upper slope positions of landscape features with more coarse-textured materials, while higher soil moisture classes are seen in lower slope positions and depressions. As intended, the hard-coded swales and wetlands make up the wettest areas of the closure landscape.

Target ecosystems based on REMR class, soil nutrient regime, and other land use considerations and stakeholder inputs are further mapped and shown as revegetation prescription areas (Figure 3(c)). Plant species within each revegetation prescription that are best suited for the particular target ecosystem moisture and nutrient conditions are identified (examples provided in Table 10) and later applied to specific areas within the closure landscape (Figure 3(c)). Mine reclamation practitioners then have an idea of how much area is needed to be reclaimed for each target ecosystem and can plan for plant species required in future revegetation activities.
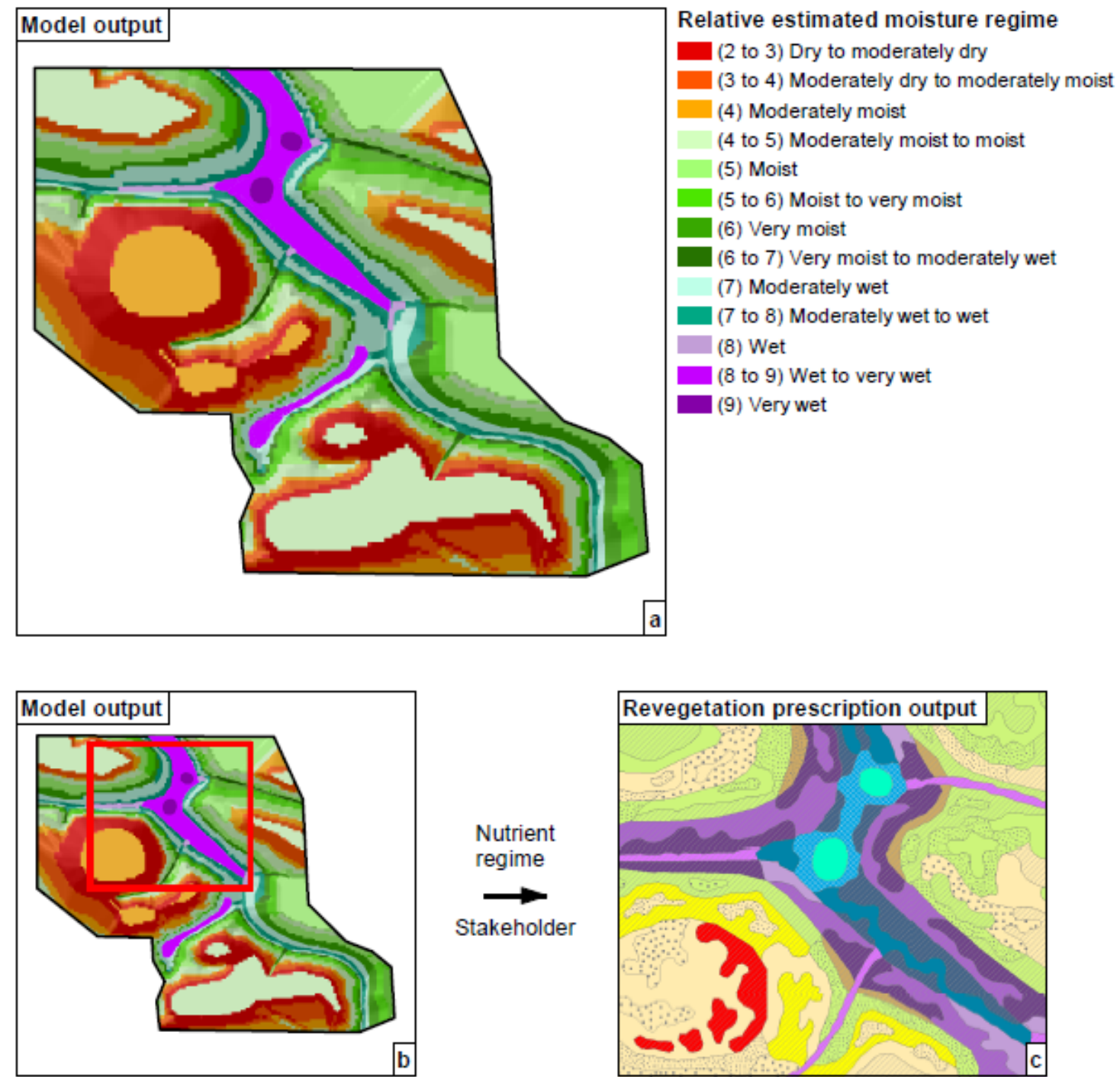

Figure 3 Model and revegetation prescription outputs to the Target Ecosystem Assessment Model for a hypothetical area showing (a) The overall output considering the available water holding capacity, macro slope position, meso slope position, slope gradient, slope aspect, and hydrology inputs; (b) A targeted area of the overall model output; (c) A theoretical revegetation prescription developed from the target area, considering the expected nutrient regime and stakeholder input 
Table 10 Examples of revegetation prescriptions for target ecosystems based on relative estimated moisture regime class and soil nutrient regime

\begin{tabular}{|c|c|c|c|c|}
\hline $\begin{array}{l}\text { Land unit } \\
\text { type }\end{array}$ & $\begin{array}{l}\text { Target } \\
\text { ecosystem }\end{array}$ & $\begin{array}{l}\text { Relative estimated } \\
\text { moisture regime class }\end{array}$ & $\begin{array}{l}\text { Soil nutrient } \\
\text { regime }\end{array}$ & $\begin{array}{l}\text { Revegetation prescription } \\
\text { examples from northern Alberta }\end{array}$ \\
\hline \multirow[t]{2}{*}{ Upland } & Dry & $\begin{array}{l}\text { Dry to moderately dry } \\
\text { (2 to } 3 \text { ) }\end{array}$ & Poor & $\begin{array}{l}\text { Jack pine, trembling aspen, } \\
\text { bearberry, blueberry, bog } \\
\text { cranberry, green alder }\end{array}$ \\
\hline & Moist rich & $\begin{array}{l}\text { Moist to very moist } \\
\text { ( } 5 \text { to } 6 \text { ) }\end{array}$ & Medium & $\begin{array}{l}\text { Balsam poplar, white spruce, } \\
\text { trembling aspen, white birch, } \\
\text { beaked willow, Saskatoon, pin } \\
\text { cherry }\end{array}$ \\
\hline \multirow[t]{2}{*}{$\begin{array}{l}\text { Transitional } \\
\text { area }\end{array}$} & Wet poor & $\begin{array}{l}\text { Very moist to } \\
\text { moderately wet } \\
\text { ( } 6 \text { to } 7)\end{array}$ & $\begin{array}{l}\text { Poor- } \\
\text { medium }\end{array}$ & $\begin{array}{l}\text { Black spruce, larch, jack pine, bog } \\
\text { cranberry, Labrador tea, low-bush } \\
\text { cranberry, green alder }\end{array}$ \\
\hline & Wet rich & $\begin{array}{l}\text { Very moist to } \\
\text { moderately wet } \\
\text { ( } 6 \text { to } 7)\end{array}$ & Medium & $\begin{array}{l}\text { White spruce, white birch, balsam } \\
\text { poplar, bog birch, red currant, river } \\
\text { alder }\end{array}$ \\
\hline \multirow[t]{2}{*}{ Wetland } & Fen & $\begin{array}{l}\text { Wet to very wet } \\
\text { ( } 8 \text { to } 9 \text { ) }\end{array}$ & Medium-rich & $\begin{array}{l}\text { Larch, willow, cloudberry, sedges, } \\
\text { peat moss }\end{array}$ \\
\hline & Marsh & $\begin{array}{l}\text { Very wet } \\
\text { (9) }\end{array}$ & Various & $\begin{array}{l}\text { Common cattail, marsh marigold, } \\
\text { softstem bulrush }\end{array}$ \\
\hline
\end{tabular}

\section{Conclusion}

To create mine closure plans with spatially explicit target ecosystem layouts, strong integration of available multi-disciplinary data and incorporating the information in a GIS environment are critical. The TEAM was developed as a process-based conceptual model within the ArcGISTM platform that uses available spatial inputs including data for geomorphic landform design, hydrology, hydrogeology, pit lake design, reclamation, and wildlife habitat, and combines them in a GIS overlay analysis.

Logical and defensible closure planning decisions are critical in negotiating and communicating reclamation plans and activities with regulators, stakeholders and other interested parties. The TEAM offers the ability to increase objective analysis, reduce inconsistency, and reduce the time required to develop target ecosystems in the mine closure landscape, through application of a more automated process to create spatially explicit REMR areas. Using the best available dataset for each variable will increase confidence in the output; however, even using basic information can yield a logical REMR output. The REMR scale (1 to 9) is a sliding scale that can be refined and customised based on specific climate and site conditions, making the TEAM appropriate to use under a wide variety of locations and conditions.

The TEAM allows for flexibility in creating a target ecosystem layout because adjustments are straightforward within the model, and are applied across the entire closure landscape. Stakeholder input and consideration of the complexity and arrangement of ecosystems can be immediately applied in the model to show where specific revegetation prescriptions are altered or changed to meet stakeholder objectives.

These attributes of simultaneous, multi-disciplinary planning information, a defensible process and output, and the ability to reflect updated stakeholder and other objectives in real time make the TEAM a useful tool for closure and reclamation planning on all types of land disturbance. 


\section{Acknowledgement}

We would like to thank our clients, Imperial Oil Resources Limited and Canadian Natural Upgrading Limited for providing us with the opportunity to work on their mine closure plans using the TEAM approach.

\section{References}

Alberta Energy Regulator (AER) 2018, Direction for Conservation and Reclamation Submissions Under an Environmental Protection and Enhancement Act Approval for Mineable Oil Sands Sites, Specified Enactment Direction 003, Calgary.

Alberta Environment 2006, Land Capability Classification System for Forest Ecosystems in the Oil Sands, 3rd Edition, Prepared by the Cumulative Environmental Management Association, Fort McMurray, Alberta, December 2006.

Government of Alberta 1993, Environmental Protection and Enhancement Act, Revised Statues of Alberta 2000, Chapter E-12, Published by Alberta Queen's Printer, Edmonton, Alberta.

Soil Classification Working Group 1998, 'The Canadian System of Soil Classification Third Edition', Agriculture and Agri-food Canada Publication 1646. 